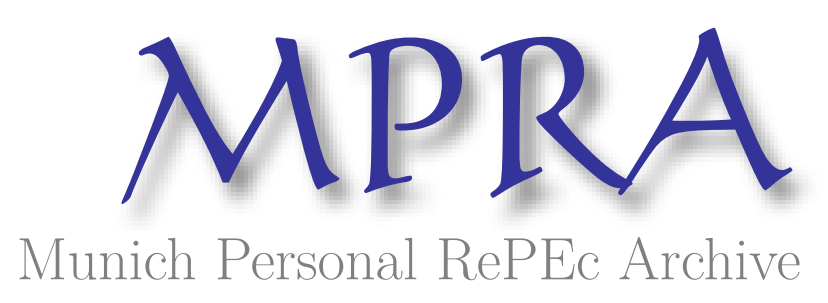

\title{
The Reform of Federal Deposit Insurance
}

Cebula, Richard

Jacksonville University

30 March 1992

Online at https://mpra.ub.uni-muenchen.de/57865/

MPRA Paper No. 57865, posted 12 Aug 2014 10:51 UTC 
The Reform of Federal Deposit Insurance.

Edited by James R. Barth and R. Dan Brumbaugh, Jr., New York: Harper Business, 1992, Pp. xxii, $310, \$ 30.00$

This paper assesses the contents of a collection of studies assembled by James Barth and Dan Brumbaugh. These ten articles combined provide us an extraordinary substantive contribution, in this instance, to the furthering of our knowledge of the very timely and significant issue of federal deposit insurance and its reform.

Joseph Stiglitz provides a brief Introduction to the book in which he stresses that the S\&L debacle has been the predictable outcome of a seriously flawed incentive structure that tis build into the federal deposit insurance system. He points out that the $S \& L$ crisis has become an economic tragedy for the country but a triumph for economic analysis, which accurately predicted the actual course of events.

In the first essay, Charles Calomiris argues that the moral hazard problem and other problems that arise in government-controlled deposit-insurance systems are likely to be observably more pronounced in the current federal deposit insurance system than in the earlier state programs that have been examined. Calomiris argues that the most desirable means by which to achieve banking system stability is to permit unlimited branch banking combined with the type of privately administered formal deposit insurance programs of antebellum Indiana, Ohio, and lowa.

In the second essay, James Barth and Philip Bartholomew argue convincingly that the major culprit in the $S \& L$ crisis is the existing structure of the federal deposit insurance system. They take the view that the Financial Institutions Reform, Recovery and Enforcement Act (FIRREA) was seriously flawed for its failure to adequately restructure the federal deposit insurance system. The authors observe that the need for reform of the federal deposit insurance system is based upon the perspective that although the system protected the small depositor and prevented widespread ruin in the 1980s, it failed to sufficiently protect the taxpayer. The authors argue that all insolvent institutions must be closed or reorganized in a timely and costeffective manner or else the losses from insolvencies will be excessive and burdensome to the taxpayers. Other reforms discussed include the use of risk-based insurance premiums or a system of co-insurance. The authors also discuss a variety of still other possible reforms, the theme being increased reliance on the "marketplace".

Next, Dan Brumbaugh and Robert Litan express the view that due to the widespread use of accounting conventions to conceal balance sheet weaknesses, the number and assets of market-value insolvent banks cannot be known with any certainty. The Brumbaugh and Litan data analysis suggests that the number of market-insolvent banks is large and their possible losses could well deplete the reserves of the Bank Insurance Fund (BIF), which did in fact happen. The critique of FIRREA stresses the failure of this law to truly address the condition of the banks or the BIF and its failure to meaningfully address deposit insurance reform.

In the fourth essay, Edward Kane argues that government deposit insurers have hidden or unacknowledged objectives and that these objectives conflict with the presumed long term goals of protecting depositors of modest means and preventing runs in a cost-effective manner. 
He takes the view that government deposit insurance funds tend to be operated in ways that are not in the best interests of the deliberately under informed taxpayers who serve as the guarantors of last resort. Kane eloquently describes how suppressing information on deposit insurance losses protects elected politicians from timely criticism for poor monitoring and poor regulatory performance. Given officials' sensitivity to media criticism, Kane argues that the most important regulatory reform is to increase accountability. He further argues that FIRREA does not make authorities more accountable for the effects of their actions. Kane proposes, among other things, that limits be established on the ways in which member of Congress can pressure regulators into giving troubled firms a break.

Next, within a public choice framework, Thomas Romer and Barry Weingast demonstrate how politicians benefited by keeping taxpayers uniformed about the thrift crisis and by establishing and enforcing a policy of forbearance. Through such actions, politicians avoided accountability, although such policies prolonged the thrift debacle and raised taxpayer costs.

Gary Gorton and George Pennacci argue that the rationale justifying traditional bank regulation is disappearing. More and more, credit and liquidity services are being separated; market driven technological innovation is separating the two activities (i.e., funding of illiquid assets with liquid deposits) that have made banks susceptible to panics. This trend presumably reflects a movement toward a more stable and more efficient system.

Robert Chirinko and Gene Guill quantitatively examine how macroeconomic shocks affect depository institutions. They argue that major problems can be encountered unless approaches to deposit-insurance reform and regulatory reform explicitly and carefully consider the impacts of such macroeconomic shocks on these institutions.

George Kaufman observes that, since 1974, the Federal Reserve has provided lender of last resort (LLR) assistance to prolong the life insolvent banks deemed too large to fail (TLTF). He argues that the LLR assistance in recent years has not saved most banks but has provided uninsured depositors time to flee without losses. This in turn has served to increase the potential loss to be borne by the FDIC. In addition, the LLR aid has been provided at greatly subsidized interest rates, needlessly adding to the cost of the TLTF policy. Accordingly, Kaufman takes the view that effective reform of deposit insurance also requires reform of both LLR and TLTF policies.

It has frequently been argues that accounting techniques have played a significant part in the interaction of depository institutions and federal deposit insurance regulation. The last two papers in this book focus on the attributes of market-value accounting. The paper by William Beaver, Srikant Datar, and Mark Wolfson take the position that it is unclear that, given the closure track record of regulators in this country, market-vale accounting would necessarily improve the efficiency with which financial institution are regulated. In the paper by George Benston, Mike Carhill, and Brian Olasov, e empirical evidence is provided to the effect that even very generic forms of market-valuation are preferred to the traditional accounting principles.

This is a book of articles written by distinguished researchers. It is a significant contribution that increases our knowledge and broadens our perspectives on an important policy issue. It should be required reading for all persons having a serious interest in making our financial system work better.

Richard J. Cebula

Georgia Institute of Technology

Page 2 of $\mathbf{2}$ 